\title{
Representations of British women at the British Empire Exhibition, 1924-1925
}

\author{
Mayuka Sato / Reitaku University / Kashiwa / Japan
}

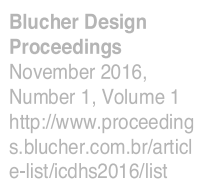

\begin{abstract}
This paper will explore how the representations of British women in the British Empire Exhibition (1924-1925) were used to distinguish Britain as the mother country of the British Empire. In 1921, the territories of the British Empire were at their largest; however, the empire was facing economic decline and fear of disintegration by 1924. The exhibition was organized based on those fears. Dominions and colonies were asked to cooperate to show the "unity" of the empire. Half the people of the British Empire were women. How, then, did the British Empire Exhibition try to incorporate women into the new vision of the British Empire? Looking at the representations of British women in the exhibition, it is possible to understand how Britain tried to propagate the image of British women to show its civilized superiority within the British Empire.
\end{abstract}

\section{Keywords}

British Empire Exhibition, representations, gender, modernity

\section{Introduction}

The British Empire Exhibition, which opened in April 1924, attracted almost 27 million visitors. It was a large event in which most of the dominions, colonies, protectorates, and mandated territories were asked to cooperate for the "unity" of the Empire. Within the 216-acre site at Wembley stood the Palace of Engineering, Industry, and Arts, pavilions of dominions and colonies, kiosks, gardens, five restaurants and 28 cafes, small churches and religious meeting houses, and an amusement park. The purpose of the exhibition was to show imperial solidarity and stimulate trade within the British Empire. The Prince of Wales' message on the opening day was that the exhibition was "presenting this picture of our Commonwealth of Nations" and giving "a living picture of the history of the Empire and of its present structure" (Knight \& Sabey, 1984, p. 12). In other words, Britain was trying to forge a new transnational image of the British Empire.

Various recent studies on the British Empire Exhibition have focused on how dominions or colonies were represented in the exhibition and how appropriate a place it was to educate people on imperial propaganda. However, it was also a place where people encountered the notions of class, race, and gender. Gendering the Fair stated that "world's fairs have tended to annunciate racial, class, and national identity in highly gender-specific ways" (Boisseau \& Markwyn, 2010, p. 3).

In Ephemeral Vistas, Greenhalgh addressed the relationship between women and international exhibitions, stating, "International exhibitions were one of the first and most effective cultural arenas in which women expressed their misgivings with established patriarchy" (Greenhalgh, 1988, p. 174). When women were depicted in the exhibition, they were seen as evidence of women's advancement into society. Clendinning dealt with the involvement of the International Council of Women (ICW) in the British Empire Exhibition. ICW proposed the establishment of the Women's Section, inspired by the Women's Board of the Panama-Pacific Exposition in 1915. The Women's Section also had the task of organizing Women's Week at the British Empire Exhibition (Clendinning, 2010, p. 116). Clendinning (2010) explained the efforts of ICW at Wembley and praised the fact that the ICW "put women on the map at the 1924 British Empire Exhibition by creating political spaces for women in the physical and the intellectual sense" (p. 126).

When looking at the displays and how women participated in the exhibition, women's active participation is obvious. Women held conferences during Women's Week on topics such as women's health, educa- 
tion, and home life. Another important conference was held from May 5 to May 8 by the ICW on the subject of the prevention of causes of war. As Clendinning claimed, at the Empire Exhibition, women were depicted as political citizens. However, at the same time, Englishwomen's traditional roles were emphasized at the British Empire Exhibition. Therefore, this paper focuses on how women's gendered role was consolidated and displayed at the British Empire Exhibition and how this gendered role was used to distinguish Britain as the mother country of the Empire. To analyze women's representations at the Empire Exhibition, this paper will focus mainly on a few particular displays that were noted in journals and newspapers.

\section{Women's section and hospitality}

How were women involved in the British Empire Exhibition? The Women's Section was established through the efforts of Lady Aberdeen, the first president of the ICW. It was given the task of offering hospitality to foreign visitors of the exhibitions and organizing Women's Week from July 21 to 26.

The Women's Section was established with Queen Mary as the patron and the Duchess of York as the president. At the second meeting of the general committee of the Women's Section, the content of their hospitality was discussed. Aristocratic ladies, such as the Duchesses of Devonshire, Atholl, Wellington, and Norfolk, offered to entertain foreign visitors with parties, and various organizations were asked to arrange sightseeing facilities and weekly expeditions. In June 1924, parties were held throughout London every week. Queen Mary held a Royal Garden Party, inviting 5,000 guests, and the government gave a garden party at Hampton Court with 2,000 guests.

These hospitalities were not planned solely for the distinguished guests. Hospitality for common visitors was also arranged. Lady Galway suggested the Empire Fellowship scheme so that British citizens could offer their houses or tours to visitors from overseas. The Manchester Guardian stated that foreign visitors were expected to go home with "pleasantest memories of England" ("England "At Home," 1924), and "a little insight into the significance of England ("Women's Week at Wembley," 1924a). British women were allotted the role of hostess to entertain guests visiting the country.

\section{Women as housewives and objects of display}

Another role that women were allotted was that of housewife. It has often been claimed that goods and products displayed at the international exhibitions labeled women as consumers (Clendinning, 2010, p. 117). Indeed, various newspapers printed articles for women readers suggesting the exhibits they should visit. The Daily Mail advertised that "a housewife who spends a day or days at the British Empire Exhibition may come away with a hundred inspirations for her home ("The Housewife at Wembley," 1924).

Even the colonial exhibits were suggested as places where English housewives could get hints for maintaining their homes. Native arts and crafts would decorate their homes, and the food produced there would enrich their menus. At the Palace of Industry, there were demonstrations on "how to cook Empire foods." Mrs. C. S. Peel (1925), a journalist, wrote that, by cooking Empire food, women were "keeping the money in the family," and women could do the great work of securing "the Imperial Economic Independence of the nation."

Using the products of the Empire meant being patriotic. The Times introduced the Empire Shopping Week, held from May 19 to 24, and explained that women were considered "principal shoppers and they could create a demand for Empire goods" ("Empire shopping week," 1924). Queen Mary even stated, "It is the home which makes the nation and which builds the Empire" ("Queen \& Importance of the Home," 1924). Women's roles as housewives and consumers were considered vital in maintaining the Empire. Therefore, for British women, being a housewife was a credential for being a citizen at that time.

Various exhibits in the exhibition especially appealed to housewives. However, at some exhibits mentioned in newspaper articles as exhibits for women, women's bodies were used for display. One popular exhibit was the gas exhibition in the Palace of Industry. A tableau of the Seven Ages of Women was shown. It revealed how gas was used in the infancy, childhood, school days, business life, middle age, and old age of women's lives, displaying "hitherto unknown methods of heating and illuminating the home" ("Women at Wembley," 1924).

Another exhibit that was frequently recommended for women was that of the Nottingham lace displayed at the Place of Industry. According to a woman correspondent from The Times, visitors from the dominions seemed to seek this exhibition as their first place to visit ("Through a Woman's Eyes," 1924).

The Nottingham lace industry was competing against European industry at that time. The Queen, a women's magazine, advertised, "Here were to be seen specimens of the immensely improved products of 
the characteristic English manufactory" ("Dress at Wembley," 1924). According to a guidebook, "Many feminine visitors, indeed, will probably vote this corner the most interesting part of the Exhibition" (A Pictorial and Descriptive Guide to London and the British Empire Exhibition, 1924, 1924). The reason that women found this part of the

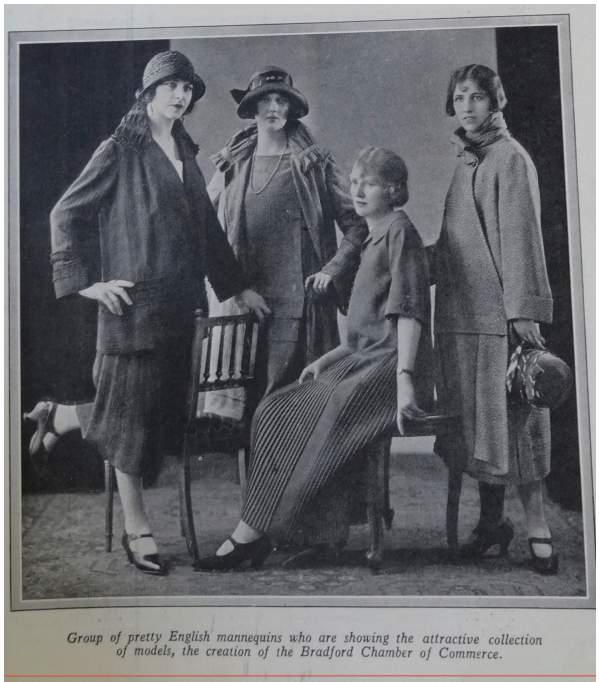

Fig. 1: Group of pretty English mannequins ("English Fashions at the Exhibition," 1924) exhibition interesting was the use of live mannequins. When the mannequins and dresses were displayed at a ball before the Duchess of Portland, the Duchess of Newcastle, and other ladies the previous year, it "evoked much praise" ("Beautiful Lace Dresses," 1923). "[B]eautiful (British) mannequins" displayed the gowns designed by M. Reville of Hanover Square ("Dress at Wembley," 1924). Similarly, the Bradford Chamber of Commerce displayed their wools with a parade of "pretty English mannequins." It was planned to show "what English makers can do, helped by English dress designers showing their work on English mannequins ("English Textiles and Laces," 1924). Each of them was "a type of English beauty" ("English Fashions at the Exhibition," 1924) (see Figure 1).

English beauties were also displayed inside a glass case at Pear's Palace of Beauty, which was located inside the amusement park.

Beauties were chosen from among famous women in history or literature such as Helen of Troy, Cleopatra, Dante's Beatrice, Mary Queen of Scots, Nell Gwynne, Scheherazade, Madame de Pompadour, Mrs. Siddons, and Miss 1924. These characters were not just beautiful but also clever women who achieved something in their lives. They were not all Englishwomen, but the women playing the roles were English or British. A picture of these women costumed as the characters appeared on the front page of The Queen (Figure 2). More than 750,000 people visited the venue (Knight, 1984, p. 74). Pear's was a soap manufacturer, so the message from the Palace of Beauty was straightforward: by using Pear's soap, women would be beautiful.

Exhibiting colonial people had been the tradition of the international exhibitions since the $19^{\text {th }}$ century, but at Wembley, English or British women also became part of the "human exhibition." In addition, British people were used to looking at women on display, as there were entertainments such as tableaux vivant in the $19^{\text {th }}$ century. At the Empire Exhibition, their physical beauty was linked to the good quality of British products.

One article in the Daily Mail concerned "England's pretty girls" who flocked to London because of the exhibition. The article tried to determine which town or village produced the prettiest girl in England, and in the end, it concluded, "in no country of the world is the standard of looks higher than it is in Great Britain" ("England's Pretty Girls," 1924). Even the English visitors were objects of display.

\section{Modernity and British women}

As we have seen, British women's beauty was displayed in connection to the good quality of British products. It also meant that women were viewed as the receivers of the fruit of progress in British industry. Labor-saving devices for the home, such as a new type of steamer that claimed to save fuel, time, and cooking space, sewing machines, and stoves, stimulated women's desire to buy. While native West African housewives were shown using primitive kitchen tools ("West African Housewifery," 1924), British woman used the latest kitchen tools at the gas exhibit.

Civilization and primitiveness were in contrast at the exhibition. While the British represented modernity, progress, or civilization, the non-British represented tradition, wildness, or primitiveness. Likewise, the Palace of Industry, Engineering, and Government pavilions were constructed in concrete, the newest building material, while the pavilions of colonies such as Bermuda, Burma, and Ceylon were made of wood. Even though the purpose of the exhibition was to consolidate imperial unity, Britain tried to differentiate itself from the others by presenting itself as the industrial country, while other parts of the Empire provided abundant raw materials.

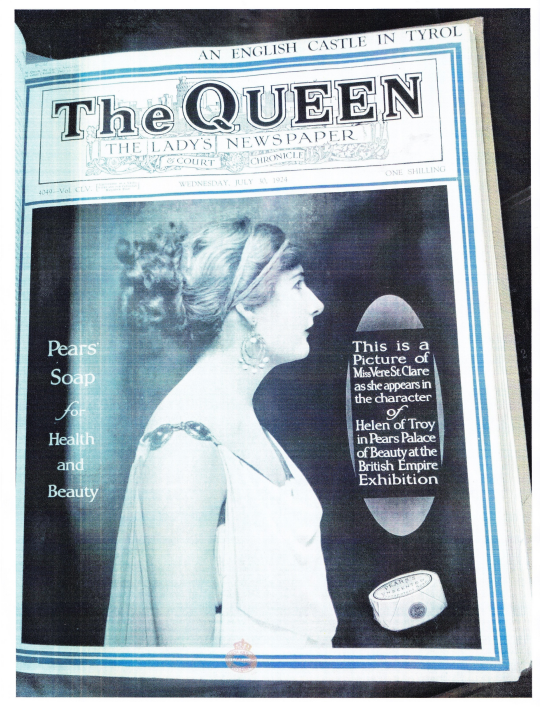

Fig. 2: Helen of Troy in Pear's Palace of Beauty ("A Picture of Miss Vere St. Clare," 1924). 
One way of differentiating Britain from the colonial parts of the Empire was to show women's participation and women's progress in society. During Women's Week, various conferences were held, and the National Council of Women established a two-room pavilion near the Government Pavilion to allow various women's organizations to hold conferences. The conferences were opportunities to learn about the other parts of the Empire, but they were also opportunities to show the visitors all aspects of women's progress after the Great War. Women's active participation in the exhibition and their social and political progress were "visible signs of modernity" (Clendinning, 2010, p. 114).

\section{Conclusion}

Wembley was a place where people could get an overview of the Empire. Even the people who had not visited dominions or colonies were able to gain firsthand knowledge of the Empire just by visiting the exhibition. However, it was also a place where British learned about their own country ("Belated Reflections on Wembley," 1924), and it was a place for foreign visitors from the Empire to learn about their mother country.

What permeated the exhibition was the intention to educate people about the history of the Empire and Britain's position as the mother country of the Empire. In the Weekly Bulletin of Empire Study, a pamphlet containing educational material, William Wordsworth's poem "The Motherland" was posted along with information about the Empire's climate, trade, history, and other educational texts (Weekly Bulletin of Empire Study, 1924, p. 5). It was stated that "[l]inks of sentiment and affection are stronger than laws and constitution" and that "a common loyalty unites" the Empire (Weekly Bulletin of Empire Study, 1924, p. 124).

During the Great War, dominions and colonies aided Britain in fighting the war. Their contribution could not be ignored. Meanwhile, the British Empire was in danger of disintegration. Dominions were becoming independent, and nationalism was stirring in Ireland, India, and Egypt. Britain was no longer able to hold the Empire by its economic power or by its army and navy. Therefore, other means to hold the British Empire were sought, sparking the idea of the British Empire Exhibition.

As we have seen, representations of British women at the exhibition aimed to differentiate Britain from other parts of the Empire. The women's civilized hospitality, physical beauty, and visible participation in society were signs of civilization and modernity that distinguished Britain as the mother country. At the same time, women's roles as housewives were emphasized in the context of civilization and modernity. The British Empire Exhibition incorporated British women as citizens who upheld the British Empire along with men, as Queen Mary stated: "[T]hough women's first responsibilities centre in the house, in these days of enlarged opportunity they do not end here" ("Women's Week at Wembley," 1924b).

\section{Acknowledgement}

This work was supported by JSPS KAKEN Grant Number 26870552.

\section{References}

Beautiful lace dresses. (1923, November 17). Manchester Guardian, p. 12.

Beaven, B. (2012). Visions of empire: Patriotism, popular culture and the city, 1870-1939. Manchester, UK: Manchester University Press.

Belated reflections on Wembley. (1924, October 3). The Woman's Leader, p. 286.

Boisseau, T. J., \& Markwyn, A. M. (ed.) (2010). Gendering the fair: Histories of women and gender at World's Fairs. Urbana, Chicago, and Springfield, IL: University of Illinois Press.

Clendinning, A. (2010). Internationalist peace activism at the 1924 British Empire Exhibition, in T. J. Boisseau \& A. M. Markwyn (Eds.) (2010). Gendering the fair: Histories of women and gender at World's Fairs. Urbana, Chicago and Springfield, IL: University of Illinois Press.

Dress at Wembley. (1924, April 30). The Queen, p. 18.

Empire shopping week. (1924, May 20). The Times, p.16.

England "At Home." (1924, July 12). The Manchester Guardian, p.8.

England's pretty girls. (1924, August 18). Daily Mail, p.6.

English fashions at the exhibition. (1924, May 14). The Queen, p. 15.

English textiles and laces. (1924, April 11). The Times, p. 17. 
Greenhalgh, P. (1988). Ephemeral vistas. Manchester, UK: Manchester University Press.

The housewife at Wembley. (1924, June 6). Daily Mail, p. 15.

Knight, D., \& Sabey, A. (1984). The lion roars at Wembley. London, UK: Barnard \& Westwood.

Peel, C. S. (1925, June 17). Imperial housekeeping. The Queen, p. 33.

A pictorial and descriptive guide to London and the British Empire Exhibition, 1924. (1924). London, UK:

Ward, Lock \& Co.

A picture of Miss Vere St. Clare (1924, July 30). The Queen, p. 1

Queen \& importance of the home. (1924, July 22). Manchester Guardian, p. 12.

Stephen, D. (2013). The empire of progress: West Africans, Indians, and Britons at the British Empire Exhibition, 1924-25. New York, NY: Palgrave Macmillan.

Through a woman's eyes. (1924, April 24). The Times, p. 14.

The truth about Wembley. (1924, July 18). The Clarion, p. 3.

The weekly bulletin of Empire study. (1924). London, UK: The Inter-Departmental Educational SubCommittee.

West African housewifery. (1924, May 6). Daily Chronicle.

Women at Wembley. (1924, April 23). Daily Mail, p. 5.

Women's Week at Wembley. (1924a, June 26). The Times, p. 11.

Women's Week at Wembley. (1924b, July 30). The Queen, p. 1.

\section{Biographical note}

Mayuka Sato is an associate professor in the Department of Foreign Languages at Reitaku University, Japan. Her research interest includes British history, especially, representations of women's suffrage movement as well as international exhibitions. 